\title{
Mihail Sadoveanu - NarRator of the Romanian VilLage
}

\author{
IULIANA-MARIA GAVRILĂ
}

\begin{abstract}
The Romanian village from the first half of the twentieth century is more than a place, it is a living body, full of meaning, symbols, life, colour, suffering, knowledge. Mihail Sadoveanu insists on showing us all these things in his works, in recording all the aspects related to this world, before it being swallowed by progress and oblivion. What we do in this article is an analysis of Sadoveanu's literature and a presentation of some aspects of the Romanian village, seen by Sadoveanu's artistic vision, but also real aspects and features recorded by documents and archives preserved since then.
\end{abstract}

Keywords Romanian village, peasant, beliefs, customs, literature.

The following article arose from the assumption that literature can be a valid source in the description of reality - an idea that underlies a larger study on literature in the interwar period.

The discussion below starts from the literature of Mihail Sadoveanu and how it describes the reality of the Romanian village and the provincial town from the interwar period. We will illustrate, through the Sadovian literature, an image of the Romanian village, of the Romanian peasant and of his life. The title of "storyteller" is one that Mihail Sadoveanu has held for a long time and is a title that has been given to him by many critics of Romanian literature. In this case, we will use Sadoveanu's "stories" to extract details about the history of the village and its image in the interwar period.

To begin with, we would like to define the technical terms we are working with, in order to clarify the margins within which this study will remain. We stated that literature can be a valid source in describing reality. First of all, the reality we

*Babeș-Bolyai University, Cluj-Napoca. ferent_iuliana@yahoo.ro.

DOI: 10.26424/philobib.2021.26.2.06 
refer to here and throughout the entire article is that of Romania between the two world wars. And when we say "reality" we mean what the historical documents illustrate: from political events, to the way society is organized, from the military events of the two world wars, to the daily life of the villagers. All of this information, taken from parishes and personal archives of different personalities, taken from memoirs or papers about the social life of that period, forms the foundation of our research, on which we then place the literature, with the details that are provided in the pages written by Sadoveanu.

Secondly, one of the definitions we would like to state here, regarding the term "real" - which concerns us in such a study -, is that "real" is something that exists independently of consciousness or will. Something that simply "is" - in other words, when we talk about literature, reality is what exists regardless of the will or conscience of the author. It is that information taken over by the author and passed on exactly as it is. Historical information - from clothing, to behaviours and social realities - all according to the space and time in which the action is placed.

In the case of Mihail Sadoveanu, the details that make up the image of the Romanian peasant belong to the period in which the author lives - he describes the image of the Moldovan village, the provincial town, the image of the author's childhood, his life, his reality. As Manolescu said, describing Sadoveanu's literary activity, the author describes the character of the peasant, as if trying to explain his behaviour and as if to help readers understand the behaviour of peasants. Through his literature, Sadoveanu becomes a teacher for all his readers. He teaches them about the village and about history - in the works of Sadoveanu, the two are one and the same, because in the village the oldest teachings and customs survive.

The author dedicates himself to writing as a peasant dedicates himself to the work of the land. Always in contact with those who make up the subject of his works, Sadoveanu describes them, he leaves us a testimony of what used to be. He even stated: "I believe in two poems of life: in the poetry of writing and in the poetry of work. And I also believe that the writer must be in constant contact with life, with its pains, with its joys, with its defeats. ${ }^{1 "}$

It is not our intention to transform Sadoveanu into a historian, or a documentary writer. Mihail Sadoveanu is par excellence a storyteller - he talks about his experiences, he writes about what he sees, he invents beautiful stories, novels and characters - all fictional, all coming from his imagination. But what I

\footnotetext{
${ }^{1}$ See Mihail Sadoveanu, Opere I. Povestiri. Începuturi [Literary Works I. Stories. Beginnings], vol. 1 (Bucharest: Editura Minerva, 1981), IX.

Original text: "Cred în două poezii ale vieții: în poezia scrisului și în poezia muncii. Și mai cred că scriitorul trebuie să fie într-un permanent contact cu viața, cu durerile ei, cu bucuriile, cu înfrângerile ei."

If not marked otherwise, all quotes were translated from Romanian by the author of the present paper.
} 
noticed is that Mihail Sadoveanu's work is impregnated with realistic descriptions of the village world, of the traditional clothing, of the customs and beliefs of that era Sadoveanu writes fiction, but documents in his works the world of the Romanian village itself. In each of his works, of any kind, we were able to discover elements that describe his present, his opinion, the world around him. We could say that the author makes a kind of documentary - he takes images, ideas, information from the village world and the society in which he lives his days, then processes this information and offers it back to society. We see how literature describes the world in which the author lives - in this case, we managed to encounter images of the Romanian peasant from Sadoveanu's characters, which although constructed fictionally, they contain real, correct and very important details regarding the image of the Romanian peasant from the interwar period.

Sadovian literature mirrors, to a certain extent, the reality of the twentieth century. The author uses metaphors, stories, figures of speech and other artifices to give aesthetics to his texts, to turn them into true literary masterpieces - but the characteristics of the village are still coming through. It is as if the author casts a veil over the reality in which he lives, but this reality is still visible. Its details are there, the events remain, the people look the same - everything describes the Romanian rural world from the interwar period, but through fictional stories.

Sadoveanu's art is not meant to be moralizing - at least according to the author. But his art illustrates reality and "humanity's aspirations for the better. ${ }^{2 "}$ Although his statements reject the art being "infiltrated by ideas," we will notice, as the argumentation in the present paper progresses, that Sadoveanu himself cannot eliminate "ideas" from his works and cannot refrain from transmitting information with a moralizing role.

Mihail Sadoveanu is indeed the village's storyteller - but what stories does he tell? The author is a supporter of the village, of the peasant, of the land, of the pains and sufferings of the village, but the most important thing is the fact that Mihail Sadoveanu was a narrator of the beauty of the village. No one else described Moldova as he did; the beauty of his native places, the love for his grandparents' village and for any Moldovan village runs through every line of his works. Therefore, above any other author, Sadoveanu is the one who writes about the village with the greatest admiration and with the greatest understanding towards its inhabitants: "In time, I got to know the expeditions of the hunt, I went through the secrets of some famous ponds, at the confluence of Jijia and Prut, near lași; my knowledge spread and I began to know the secrets of great Danube Delta; then I went up the mountain. After the First World War, I moved to more distant places, in the country of Transylvania. Thus, I saw how people from all over old Dacia live; I paid attention to their way of speaking; I understood that Moldovans are great-grandchildren of

\footnotetext{
${ }^{2}$ See Sadoveanu, IX.
} 
Transylvanian shepherds; I became more and more acquainted with the truth that our ancestors were natives of a deeper antiquity than the conquering expedition of roman Emperor Trajan. The past and the sufferings of the working people became clear to me: I knew them in their actions and their knowledge..."

Through his literature, that became extremely popular, Sadoveanu actually created an empire of the Romanian village. Any topic he approached and even if he placed the plot in the city, Sadoveanu brings the village to the forefront in everything he writes. Thus, we observe what the author wanted to achieve: an approachable literature, accessible to all, through which he could tell everyone about the village, about the rural world and its universe.

Seen as a whole, Mihail Sadoveanu's work shows the signs of the way his creation evolves; thus, there are three great periods in which we can frame Sadoveanu's works: the period 1904-1917, represented by the period in which the author tests the literary world, a naïve period, in which marks the rise of the young Sadoveanu. The period 1917-1929 is marked by the war that had taken place and we notice the author reaches a literary maturity, he begins to address realistic themes, which present a less idyllic universe and characters tried by hardships, as witnessed by the author himself. The last period is that of artistic maturity, starting with 1929. From this point on, we can discuss about symbolism in Sadoveanu's works, about a philosophical vision of traditional myths and symbols; now the author brings forward stories and legends from villages and gives them hidden meanings, which, once deciphered, describe the society in which Sadoveanu lives.

The first stories of our author, all his experiences in his grandfather's village, the way he interacts with the villagers, the "adventures" he has here, everything appears in his literature, especially in the "Years of Apprenticeship": "These stories of the beginnings of me, some written at the age of seventeen, dealt with a little-known world, most of my characters were simple people from the country, with whom I had spent time in the enchanting landscapes of northern Moldova. I read easily in their souls; they were dear to me; I was suffering and I was happy with them. I saw nature through them. I associated the earth and the sun, the forests and

\footnotetext{
3 Ibid., VI.
}

Original text: "Siretul, Moldova, regiunea dealurilor, spațiu destul de restrâns, au alcătuit cadrul școalei mele. Cu vremea, am cunoscut expedițiile la vânatul de codru, am străbătut tainele unor bălți renumite, la confluența Jijiei cu Prutul, lângă lași; cunoașterile mele s-au întins în tainica și măreața deltă a Dunării; apoi am suit la munte. După războiul cel dintâi mondial, am trecut în locuri mai depărtate, în țara Ardealului. Astfel am văzut cum trăiesc oamenii din toată Dacia veche; am fost atent la felul lor de a vorbi; am înțeles că moldovenii sunt strănepoții păstorilor ardeleni; m-am pătruns tot mai mult de adevărul că strămoșii noștri sunt autohtoni dintr-o vechime mai adâncă decât expediția de cucerire a împăratului Traian. Trecutul și suferințele poporului muncitor mi-au apărut limpezi: le ceteam în fapte și cunoașteri..." 
the waters with the lives of these brothers, whom I felt coming to the new times from the deepest past, carrying the burden of persecution and exploitation. I had learned the language in which I wrote my stories from them. I instinctively tried to give meaning to the dramas I portrayed. I didn't tell stories without purpose. Age and experience have deepened these qualities, that now seem to me necessary as a foundation of our art. ${ }^{4 \prime \prime}$ Constantin Ciopraga said that it is not forests and ponds that Sadoveanu painted in his literature, but what is hidden in them: their soul and their rhythm. ${ }^{5}$

In "Years of Apprenticeship", the author reveals a lot about himself: from stories about where he grew up, to statements about the things that motivate and excite him. Here he states that "the situation of the peasants has been, in my artistic career, an early concern. I was primarily interested in the colourful speech of the dwellers near the water of Moldova. Everything that was new and beautiful caught my eye. I also wanted to remember the ritual of peasant life and the inflexible law of their tradition. I was also interested in the dignified, archaic and original way in which these people of the past appeared to me, in all the manifestations of public life. I was fully won over by everything I considered noble and beautiful in their lives, removing all that was scum, misery, and secular humiliation. I understood clearly since then that, under the mountain, at the water of Moldova and up to Siret, there lived other type of people than on the Prut. ${ }^{6 \prime}$

We see here that separation between the two Romanian worlds: that of the village and that of the city, but here we encounter something new, something that

${ }^{4}$ Ibid., 5-6.

Original text: "Aceste povestiri ale începuturilor mele, scrise unele la șaptesprezece ani, se ocupau de o lume puțin cunoscută, oameni simpli de la țară cei mai mulți, cu care petrecusem în peisagiile încântătoare ale Moldovei de miazănoapte. Ceteam cu ușurință în sufletul lor; îmi erau dragi; sufeream și mă bucuram cu dânșii. Natura o vedem prin ei. Pământul și soarele, codrii și apele le asociam cu viața acestor frați, pe care îi simțeam venind spre timpurile nouă din cel mai adânc trecut, purtând povara persecuțiilor și exploatării. Limba în care îmi scriam povestirile o învățasem de la ei. Din instinct cătam să dau o semnificație dramelor ce înfățișam. Nu vorbeam și nu istoriseam fără scop. Vârsta și experiența au adâncit aceste însușiri ce mi se par și astăzi necesare la temelia artei noastre."

${ }^{5}$ See Constantin Ciopraga, Mihail Sadoveanu. Fascinația tiparelor originare [Mihail Sadoveanu. The fascination with originary patterns] (Bucharest: Editura Academiei Române, 2006), 13.

${ }^{6}$ See Mihail Sadoveanu, Anii de ucenicie [Years of Apprenticeship] (Bucharest: Editura de Stat pentru literatură și artă, 1958), 204-206.

Original text: "această 'chestie' (e vorba de chestiunea țărănească) a constituit, în cariera mea artistică, o preocupare precoce. Mă interesa în primul rînd vorbirea colorată a pămîntenilor de la apa Moldovei. Tot ce era nou și frumos îmi strunea atenția. În aceeași măsură îmi solicita luarea-aminte ritualul vieții țărănești și legea inflexibilă a datinilor. Mă interesa și felul demn, arhaic și original în care mi se înfățișau, în toate manifestările vieții obștești, acești oameni ai trecutului. Eram deplin cîștigat de tot ce socoteam eu nobil și frumos în viața lor, înlăturînd tot ce era scorie, mizerie și umilință seculară. Înțelegeam deslușit încă de atunci că, sub munte, la apa Moldovei și pînă la Siret, trăiește o altă rasă decît la Prut." 
we will encounter throughout Sadoveanu's work: the deification of the village. For Mihail Sadoveanu, unlike most authors who still write about the village and the peasant, this world is a pure, perfect one, which suffers because of others but which should never change. For Sadoveanu, the village is a source for all that is good, it is a place of peace and quiet, a place where evils enter only if they are brought by foreigners. This is a conception he came in contact with through his grandfather.

Here, in the "Years of Apprenticeship", Mihail Sadoveanu begins for the first time to show his readers the impasse in which the archaic civilization finds itself, ${ }^{7}$ in terms of the changes that take place more and more due to the modern world, which continues to develop, ignoring the needs of the simple traditional man. Also, starting with the "Years of Apprenticeship", another feature of Sadoveanu is made known to us: the concern for nature and the way man relates to it. Throughout his works, we will see how the author seeks to "decipher the testamentary Mioritic message" - in other words, he tries to explain the old world of the villager, through his connection with the peasants, through the "mystical understanding of (his) connection with the man of the earth and the ancient civilization of the Romanian village. ${ }^{8 \prime}$

Although the village and the peasant are clearly favoured in the works of our author, his works are not exclusively rural-themed. He also writes novels with modern themes, placed in the world of cities or provincial towns, with main characters that are modern, urban people. But through these works, the author only strengthens his opinion on the decadence of the modern world. Industry, machinery, capitalism - all these are phenomena with which Sadoveanu is not compatible.

Mihail Sadoveanu will also participate in the First World War, as a lieutenant (he was even taken prisoner in Bulgaria). This event will mark him deeply: he suffers greatly for the human losses from the war and exposes in his literature all the horrors he encounters during this gruel conflict. Moreover, he launches an antiwar campaign initiative, and together with several fellow writers he tries to shed light on the harmfulness of this phenomenon. His writings on the war are very impressive and have a strong impact on readers. This time he does not focus only on the peasant, he describes the situation in the cities in particular. But the fate of the peasants in the war is very clearly described.

From 1916, our author becomes a corresponding member of the Romanian Academy. In 1923 he will give his reception speech at the Romanian Academy and will talk about "Popular Poetry", declaring himself a "disciple of Neculce ${ }^{9}$, Creangă $^{10}$

\footnotetext{
7 See Nicolae Florescu, Sadoveanu între realitate și mit [Sadoveanu - between reality and mith] (Bucharest: Editura Jurnalul literar, 2011), 260.

${ }^{8}$ See Florescu, 260.

${ }^{9}$ Ion Neculce is a writer and boyar that lived in the $17^{\text {th }}$ century and wrote Letopisețul Tării Moldovei, one of the most important chronicles in the Romanian culture.

10 Ion Creangă is a Moldavian writer who lived in the $19^{\text {th }}$ century, considered one of the classics in the Romanian literature.
} 
and of popular creation, ${ }^{11 "}$ a disciple of all those great men that came before him and that were preoccupied with the same rural world of the Romanian village. Towards the end of the interwar period, Sadoveanu published a lot, almost annually, and obtained positive and praiseworthy reviews of most of his works, especially novels (Baltagul, Nunta Domnitei Ruxandra, etc.).

Mihail Sadoveanu becomes the writer of "provincial environments in which drifting souls agonize, ${ }^{12 "}$ he is the one who describes the urban environment as an environment of light morals, of perdition. He is the opposite of Caragiale, ${ }^{13}$ who in his literary works ridicules morals, the city and all the negative things; he is not like Rebreanu ${ }^{14}$ either, who barbarizes everything to the extreme. Sadoveanu is more sentimental, he is visibly saddened in his writings, by what is happening around him. His literature cannot hide the way he thinks, how he feels, we can see Sadoveanu through the lines, speaking through his characters. Sadoveanu is not a man who can easily get over the negative things that happen in his country, with his peasants, with his world.

The first aspect that we will develop next, related to Sadoveanu's literature, is the attitude of repulsion towards the urban world - an attitude that appears constantly in his work.

The two worlds (that of the village and that of the provincial town or the city) are presented antithetically in absolutely all of the author's works and because he writes in a time of change, in a century in which one world fades and another now takes shape. The works we focused our attention on for this presentation are those of the early twentieth century. Writing in the interwar period, witnessing historical events that drastically change society and the world in which he lives, the author presents through any theme he addresses the feeling that one world ends and another takes its place.

The landscape of Sadoveanu's novels shows an incipient modernization, the changes that take place being timid at first and gradually accentuating to the point where suddenly the world of the city is unrecognizable. For the village world, any change is shocking, it has the potential to interrupt and stop the normal course of life. The formation of large industries, the migration of labour to provincial towns and cities, inventions such as the train, the telephone, all these are great changes in the course of the world, for those who live in rural areas. If for us the invention of the telephone does not seem to be so disruptive, for the villagers this machine is

${ }^{11}$ See Mihail Sadoveanu, Nunta domniței Ruxandra. Vremuri de bejenie [The wedding of Lady Ruxandra. Times of war] (Bucharest: Editura Minerva, 1977), XXXVIII.

12 See Sadoveanu, Opere I, XVII.

13 Ion Luca Caragiale, Romanian writer who lived in the $19^{\text {th }}$ century and is considered one of the greatest playwrights of the Romanian culture.

14 Liviu Rebreanu, Romanian writer who lived in the $19^{\text {th }}$ century and is a writer of realist novels about the peasant. 
devilish because they do not recognize its usefulness. The world of the village is immovable and immutable, it does not change, only very rarely and very slowly; the twentieth century brings major changes very quickly, and what emerges in Romanian society is a mixture between traditional, patriarchal, archaic and industrial, modernization, adaptation.

The "mechanical" civilization infiltrates the world of Sadoveanu's beloved village; the author sees the "irreversible fragmentation" of archaic civilization under the "relentless plough of progress. ${ }^{15 "}$ It is a drastic point of view, which sees this change exclusively negatively. The author militates for the preservation of the village world and for the preservation of the old values precisely because he sees that this world is in danger of changing beyond any recognition. From this angle, the entire Sadovian literature is created, full of descriptions of idyllic landscapes, heroizations of village characters, beneficial and positive examples from the rural world.

The author's vision at the beginning of the century is apocalyptic, as far as the Romanian village is concerned, because he witnessed the irremediable changes mentioned above. It is a romantic and melancholic vision, which shows us the tragedy of losing the old world. We notice this especially from the description that the author offers in connection with the village where Ion Creangă grew up, which at the beginning of the $20^{\text {th }}$ century had already become a small town: "The village of old Creangă is now the fourth neighbourhood of Târgu Neamțului; the civilization of the dirty, loose city conquers it quite quickly and soon no one in those places will remember that peasants used to walk there, on narrow streets, shaded by trees, Romanians in white robes, dancing and singing, that on autumn nights the merriment and the laughter and the songs of the lads and girls flowed in the streets like the wave of the clear Ozane (...) and soon a curious traveller, crossing the bridge of the little creek that washes the impurities of the town, will stop and he will ask: where is that village of hardworking people, the village of free peasants? ${ }^{16 "}$ We could not find a better comparison in Sadoveanu's works, described as the

15 See Ioan Oprișan, Natură - om - civilizație în opera lui Mihail Sadoveanu [Nature - man civilization in the literature of Mihail Sadoveanu] (Bucharest: Editura Minerva, 1986), 184.

16 See Mihail Sadoveanu, Opere 4. Duduia Margareta, 1908 - Oameni și locuri, 1908 Cântecul amintirii, 1909 - Povestiri de sară, 1910 [Literary works 4. Miss Margareta, 1908 People and places, 1908 - The song of remembrance, 1909 - Evening tales, 1910] (Bucharest: Editura de Stat pentru Literatură și Artă), 123.

Original text: "Satul lui moș Creangă acuma e despărțirea a IV-a a urbei Târgul Neamțului; civilizația de mahala îl cucerește destul de repede și în curând nimeni pe acele locuri nu-și va mai aduce aminte că odinioară umblau pe-acolo, pe uliți înguste, umbrite de arbori, români în straie albe, că se încingeau hori cu chiuituri năzdrăvane, că în nopți de toamnă veselia și gluma și cântecele flăcăilor și fetelor curgeau în șezători ca și unda limpedei Ozane (...) și-n curând un călător curios, trecând peste podul pârăului care spală necurățeniile târgului, se va opri în loc și se va întreba: unde să fi fost satul acela de oameni harnici și gospodari, satul de răzăși?" 
differences between black and white. The white streaks of the merry peasants are contrasted with the impurity of the muddy town. Clear Ozana becomes an unknown, dirty stream. The hardworking peasants' village becomes the wanderers' slum. "The cleanliness of the land of our fathers" is replaced with the "the filth of the cities, the poverty of some slums of savages, this nest of plagues from which winds of diseases of the soul and misfortunes flow to the villages. ${ }^{17 \prime}$ Throughout this description we find the atmosphere of the period in which the author writes and the feeling of inevitable change. But it is not the positive feeling, described in history textbooks, on the subject of progress and modernization; it is the negative feeling of losing some essential elements of the Romanian culture. The disappearance of Creangă's village appears as the disappearance of the author himself.

Another phenomenon outlined by Sadoveanu in his literature is that of people from rural areas who abound in cities and provincial towns in search of enrichment. This phenomenon is very well identified by the author, since it was quite common in the interwar period. There is a migration of labour from rural to urban areas. It is what the author calls the death of the village world, customs and traditions. The young generations, who already left the village due to the mobilization on the front, are looking for sources of money, they are looking to get rich faster, they are looking to raise their economic, social, identity status.

In the context in which mechanization becomes popular in Romanian cities, and factories turn some cities into industrial cities, we understand the fear that the originality of the village will disappear. Especially when that originality lies in the archaic working methods: weaving, making traditional clothing, tanning, making "opinci ${ }^{18 ",}$ pottery and making specific vessels with traditional decorations etc. All this is starting to be done mechanically and much faster and cheaper, so it is understandable that there is a decrease in demand for traditional products. And this leads to the need to engage the peasants in new activities. Activities offered by expanding cities and the modern world. Younger villagers start working in factories, but also women in weaving factories or agriculture, working not their own materials or land, or for their own profit, but working for a salary, on someone else's land and for someone else's profit. It is a reality that seems to be repeating itself, only that the boyars who owned peasants in the past is replaced by large companies, and the working conditions have changed.

"The invasion of the new world is a fatal phenomenon; life changes imperceptibly and incessantly. Little by little the sons of this land will join Europe. We should be happy that we still keep some treasures of the past and that, by their

\footnotetext{
${ }^{17}$ See Sadoveanu, 124.
}

Original text: "Curățenia pământului părinților noștri," "murdăria orașelor, sărăcia unor mahalale de sălbatici, cuibul de molime din care curg spre sate vânturi de boli sufletești și nenorociri."

18 "Opinci" are Romanian traditional footwear, made out of tanned leather and strings. 
nature, our people are still quite resilient. Nowhere, I think, are human groups guided as much by the past as the Romanian people are. Tradition is still a strict law of this nation. This law allowed the peasant to develop in a certain way, it imprinted on him a certain unique character, which constitutes the true unity of the villagers. For centuries, tradition has united the people, with all the declines of political life. ${ }^{19 \prime \prime}$ We see here Sadoveanu's stubbornness - even if the village is faced with the inevitable modernization and even if this modernization is necessary, the village will remain the "guide" in this process, being the provider of stability and fairness and originality of the Romanian people.

For example, in the short story "La sfârșit", the main character "is estranged" by leaving his native village and finds peace only when he returns: "Brother Marcule, do not ask me where I wandered, better ask me where I have not been. I walked all over this country of Romania and how many did I see! My Lord! I thought it would be good for me, but only upon my enemies I wish the luck that I have had. And I was a wicked man and found myself in the dung and ate the bread of bitterness. My years have passed bitterly in smoked taverns ... ${ }^{20 "}$ We noticed the colourful figures of speech with which the character describes his life outside the village; the "bread of bitterness" shows us how the author sees leaving the village. The description offered is not necessarily far from the truth, the lack of infrastructure and hygiene in cities is well known, especially in full modernization. Thus, the reference to dung and mud and the unfortunate fate of the character is actually a fairly accurate description of the reality of those times; but we also see here something captured from the attitude of those who remain in the village, thus surprising one of the essential characteristics of the popular, traditional mentality. The one who leaves is transformed into a stranger in the mentality of the villagers; it is a very vivid feature of the Romanian village. The one who leaves the village is no longer "one of them" because he leaves the place for which he was born. And

\footnotetext{
${ }^{19}$ See Sadoveanu, Anii de ucenicie, 298.

Original text: "Invazia lumii nouă e un fenomen fatal; viața se schimbă nesimțit și necontenit. Încet-încet se vor adăogi Europei și fii acestui pămînt. Ne putem socoti fericiți că noi mai păstrăm totuși unele comori ale trecutului și că, din firea lui, poporul nostru e încă destul de rezistent. Nicăieri, socot eu acum, grupele umane nu se mai află călăuzite în așa măsură de trecut ca poporul romînesc. Datina e încă o lege strictă a neamului. Această lege i-a îngăduit să se dezvolte în anume chip, i-a imprimat anume caracter unic, care constituie adevărata lui unitate. Din veacuri datina a unit întreaga seminție și întru aceasta ea și-a păstrat biruința, cu toate scăderile vieții politice exterioare."

20 See Sadoveanu, Opere alese I, 163.

Original text: "-Hei, măi frate Marcule, nu mă întreba pe unde am colindat: întreabă-mă pe unde n-am colindat. Am umblat toată țara asta a României și câte n-am văzut! Vai de capu meu! Am crezut c-oi da de bine, dar numai dușmanii să aibă parte de binele meu. Și m-am ticăloșit mă, și m-am tăvălit în glod și am mâncat pâinea amarului. Anii în fiere mi s-au scurs șin crâșmele afumate..."
} 
automatically, everyone who leaves the village has a cruel fate. There is no character, in Sadoveanu's entire work, to have left their native village and achieved something with their lives.

More about the village and the city and how the images of the two intertwine throughout his works we find from the author himself, who states that he understands Romania's need to become a true part of Europe and to modernize but he is governed, in this scenario, by the fear that all legacy of the village would be lost: "I understood the need for this nation to align with the other countries of Europe and at the same time I was overcome by the regret that all our originality would be lost in such a transformation. This dilemma definitely placed me in a kind of conservative democracy; the relative solution of the unknown, I still don't see. ${ }^{21 "}$ This originality that Sadoveanu sees in the villages is in danger of being lost for a main reason - the fact that the village's cultural heritage is transmitted orally. All peasant originality is stored in the oral memory of the village, so modernization threatens the loss of information, customs, habits, etc. Modernization attracts young people to cities, to a better lifestyle, leaving the village without descendants to carry on traditions.

Keeping the village traditions alive now seems to be much more important. Simple customs such as the funeral, the wedding and the simple gestures made by the Romanian peasant become gestures of our ancestors, preserved by the village world. Not only the village is threatened by the development of cities and industry, but the "deposit" of our ancestral culture is threatened as well. The collective oral memory, the one that stores all the gestures and customs from ancient times, cannot be passed on, because the sons of the village begin to leave their home.

The values, the treasures that the traditional man wants and seeks consist in religion, tradition, the "legend and the song" - in other words, exactly those behaviours that are transmitted to him orally, from ancient times. Song, ballad, myth - these are the instrument through which information is stored in oral memory and passed on.

An important part in the analysis of Sadoveau's work must be the study of the symbols placed in various novels or short stories, which refer to the peasant culture and the way it manifests itself in the villages. Trivial things like natural elements are seen in a certain way by the villagers. We are talking here about a culture that interprets any climate change and that gives meaning to everything around us. Yes, the culture of the villages is also based on the Christian religion, but it is a Christianity constantly impregnated with symbols, myths and stories, with

\footnotetext{
21 Ibid., 204.
}

Original text: "Înțelegeam nevoia intrării acestui neam în curentul de europenizare, și în același timp mă biruia părerea de rău că i s-ar prăpădi, în asemenea prefacere, toată originalitatea. Dilema aceasta m-a situat definitiv într-un fel de democrație conservatoare; soluția, relativă, a necunoscutei, încă n-o văd." 
pagan references. In the Romanian village we encounter the intertwining of the mystical, old beliefs with the official religion, with the Christian church. Sadoveanu also tells a series of myths and stories that are "left from our ancestors," using them to anchor the existence of the Romanian village over the millennia. We noticed that the author has this mania to motivate every action that the Romanian peasant does and to give it historical significance. Sadoveanu is passionate about the roots of the Romanian people and constantly, in his literature but also in his public discourse, seeks to show the old and eternal connection of the village with the history, spirituality, originality of the Romanian people.

One of the symbols so present in Sadoveanu's works is water. For the traditional man, elements such as the reflection of a lake represent the origin of life or the mirror of heaven. Sadoveanu uses the aquatic environment to place different legends or events and describes the aquatic universe and his passion for fishing as a mystical occupation. In "The Kingdom of the Waters" the character of the emperor of the waters is made known to us, and his kingdom, although it is a simple puddle, seems different in the diffused light of the sunrise. We see how the peasant finds fishing to be a possibility to return to an archaic world of archetypes. The characters we meet here are wanderers, who use that pond as a source of life: it gives them spiritual and physical food, it gives them water, it gives them shelter. Therefore, water is life.

Customs that seem remnants of ancient Dacian rituals are exemplified in the Baltagul: in a village called Cruci, Vitoria notices that a wedding is taking place. One of the inscribed habits is practiced by men, who "shot with pistols over the trees, to scare and drive away the winter. ${ }^{22 "}$ This habit is very similar to shooting arrows in the sky to calm various natural phenomena (a habit popularly known to be practiced by Dacians in ancient times). The same connection to the past appears here, which transforms the Romanian village into the millennial village. It does not seem entirely absurd to think that these customs were perpetuated from ancestral elders, all the more so since they occurred in such an isolated community. And the idea of making a symbolic gesture in an attempt to control a natural phenomenon can have profound meanings for the members of that community. We notice how any gesture, no matter how absurd or minor, has symbolic charges for people and has the potential to help and make their lives easier.

Another mystical element is fire, automatically attributed to the space of light. Especially in Hanul Ancuței, the author transforms fire into the engine of the whole atmosphere, into a beneficial, curative element. The fire is the one which maintains the course of the story and protects those around it from the threats of the night. We notice that once the fire starts to go out, the "elements" of the night appear and people begin to feel how the devil reaches them. Once the fire is

22 See Mihail Sadoveanu, Baltagul [The hatchet] (Bucharest: Editura Minerva, 1981), 166. 
extinguished, people are numb, sleep deprived and the pleasant and friendly atmosphere disappears. Numbness and drowsiness are therefore not seen biologically, naturally; they are not blamed on the large amounts of wine drunk or natural fatigue after a night of storytelling. This is what traditional thinking means - it is not logic that comes to the fore front, but mysticism. The darkness and the unknown brought about by the lack of light generate stories and beliefs that are stronger than any logical explanation. For the Romanian peasant, the devil in the dark, unseen, but felt, is more real than the effects wine has on the human body.

We believe that these beliefs and the strength with which they are believed in is a fascinating thing. It is the strength and security of their faith that makes the Romanian peasants resist in their patterns for millennia - as Sadoveanu states. This popular culture and all the superstitions and myths created by our ancestors have such power that we meet them even today, in the modern world. Although the world of the village as it was in the interwar period or even earlier does not exist anymore, certain practices are preserved. The strength with which the peasant believes in his superstitions is still active in completely different contexts, as is the case, for instance, of a housewife in an apartment building in the middle of Bucharest, who feels fear when she accidentally spills salt or takes three steps back when she sees a black cat. This old belief system still remains in the subconscious of some of us; we still practice things we learned from our grandparents, though we do not know why. We still have the reluctance to take out the garbage in the evening, but we don't know the reasons why we feel these restrictions. It is a proof of how the traditional world worked, a proof of how these customs are spread and how some symbols are understood by the modest judgment of the uneducated village man.

We believe that it is very important to keep these beliefs and customs as long as we can, to identify and retain them, because they make up the identity of the traditional man, the national identity, if we can say so. There are elements that build the image of our origins. Because, as Liviu Rebreanu stated, wherever we are now, we all came from the village, this being the place where we all have our origins, even if we do not remember.

A poet of the people, as he was also called, Mihail Sadoveanu introduces in his novels and short stories myths disguised in the form of stories. The role of these myths is to elevate the literary work and to introduce new data to be analysed. The myth, for the Romanian peasant, was not a fictional story; for the people of the villages these stories are very credible and represent the foundation of their faith. We analyse these myths in order to have a clear image of the village, from an anthropological point of view. Among the myths we have found, there are the memorial ones: the stories that tell the deeds of ancestors, of the heroes of ancestral culture - among them are, for example, the invention 
of the first tools or stories about heavenly wars and great deeds that somehow affect daily life. Phenomenological myths are those that explain certain meteorological or cosmic phenomena, and the resulting stories have to do with the making of the world out of primordial chaos, the first female and male people and thus creating the first pair, eschatology or various natural phenomena (succession of days and of nights, storms, thunder, lightning etc.). Another category of myths that we want to name in this paper would be the transcendental ones; these types of stories refer to destiny, the dual universe (Good versus Evil, Light as opposed to Darkness), the human condition, life and death and other such concepts that are explained through metaphors and stories. There are also cosmographic myths, which include the divine framework: the world of the gods, the sky, the earth, the divine world, the human world and the demonic world ${ }^{23}$ etc. All are present in the belief system of the Romanian peasant, intertwining with Christian stories and beliefs - but this intertwining appears somehow organic, not forced. In the Romanian space, Christianity is naturally combined with certain pagan practices and the ritual gestures made by the Romanian peasant do not appear as sins or actions against the approaches dictated by the Church, but on the contrary - they seem to support religiosity.

This is also where magic comes in, so present in the village and so related to the spirituality of the peasant. Any bad symptom is attributed to spells and charms; and this is no exaggeration, the charms and enchantments being practiced very often by the women of the villages. Enchantments and ritual gestures are part of the image of the rural world and at the beginning of the twentieth century, they are as present as ever. For example, Sadoveanu shows us in "The Blue Crow" how one of these spells is practiced by Varvara, by the fact that she took "a flea in a needle tip - and enchanted him and imagined to see me in a spearhead. ${ }^{24 "}$ Enmities between women are often resolved by such charms and spells in the author's vision.

Also, for such charms to work, a series of steps must be followed and a series of "mysteries" must be known; certain words must be uttered in certain moments of the night and the day, in certain places..$^{25}$ Thus, we notice how traditional culture is very easily threatened - these secrets should not be known by anyone, they are not recorded elsewhere than in oral memory, or in novels like Sadoveanu's, by authors who observe behaviours and write them down. But the meanings remain lost: Mihail Sadoveanu notes the behaviour he sees in his grandmother, he also notes how certain enchantments are made, but the words

${ }^{23}$ See Raluca Sabina Lascu, Sadoveanu - monografia satului arhaic [Sadoveanu - a study of the archaic village] (Deva: Casa Corpului Didactica Deva, f.a.), 7.

24 See Mihail Sadoveanu, Cocostârcul albastru [The blue crow] (Bucharest: Editura Cartea Românească, 1945), 35-36.

25 Ibid., 72. 
spoken remain incomprehensible and some gestures made have no meaning for the one who observes them. An important part of the image of the Romanian village is precisely this spirituality and this enigmatic behaviour practiced by females. Their understanding is reserved for a person accepted in the community of the village and this is very difficult to achieve in the Romanian space.

The most interesting thing about curses and enchantments was that the only antidote to such charms was prayer and blessings offered by priests. It is one of the main features of the Romanian village, of the Slavic world in general: the combination of pagan practices and beliefs with the Christian-Orthodox religion. We see how organized religion is the supreme authority, but pagan practices are everyday practices. Thus, the traditional Romanian belief system combines myths and stories such as the one narrated by Nechifor Lipan in the introduction of Baltagul, with elements of Christian religion; we see how the Romanian peasant follows the "old calendar", the one from the beginning of the world, with all the practices dictated by oral memory, but at the same time he obeys the laws of the orthodox church.

Mihail Sadoveanu stated that through his literature he tried to find the meanings of the traditions, "paleologies and heresies ${ }^{26 "}$ that he encounters in traditional culture. He calls the belief system he comes to know as the "old religion of this earth," without linking it to Christianity or any other religious form of worship. Christianity is called "the new religion," and the author appreciates that it "could only replace the powers of the past in part and superficially. ${ }^{27 "}$ For the author, the new religion is directly related to modernization - he is of the opinion that once the new one enters the world of the village, the connection with nature begins to be lost.

We understand why Mihail Sadoveanu presents these practices in great detail and why his entire literature is dedicated to the rural world - it is a record of all the elements observed by the author, which illustrates why the conservation of the village is so important. But the author's own works represent a method of preserving the traditions and characteristics of the village, because among his works are included many of those gestures, words, myths, stories, behaviours threatened by progress.

Here, the importance of literature comes into play: having been put in the situation when his beloved village is threatened and the reservoir of lessons learned from the Romanian peasant is being lost, Sadoveanu turns his pen into an instrument. An instrument to help him record as much as possible of the teachings of the village, of the behaviours he observes, of gestures, rituals, words,

\footnotetext{
${ }^{26}$ See Mihail Sadoveanu, Creanga de aur [The golden branch] (Bucharest: Editura Cartea Românească, 1993), 7.

27 Ibid., 7.
} 
enchantments - he pours all these into his literature and passes them on to the society in which he lives. Moreover, through the fiction he builds around these gestures and behaviours, the author attracts readers - a beautiful and captivating text has the gift of delivering more information than a rigid and dry text. A captivating text also ensures that the information delivered is retained and stored by readers - in this way, Mihail Sadoveanu also ensured that the cultural wealth in his village is passed on to the next generations. 